\title{
Computerised storage of igneous geochemical data
}

To meet the ever increasing amount of geochemical data which is becoming available, the editorial board has decided that it should become the policy of the Transactions of the Royal Society of Edinburgh: Earth Sciences to utilise computerised storage for these data. The principle will be that the geochemical analytical information contained in all papers accepted for publication in the Transactions should be stored in the UK-IGBA file presently housed by the British Geological Survey in association with the National Geochemical Data Bank in London and by agreement with the Royal Society; the file is part of IGCP Project 163-World Data Base for Igneous Petrology.

At present, only igneous rock geochemical data are to be stored. The data which will be accepted are one or more of the following items: major oxides (minimum of 5); minor and trace element contents (minimum of 5); isotopic analyses. Besides recording the rock name, number, locality, and method of analysis, it is hoped that authors will also supply petrographical and mineralogical data on the analysed samples. Such information greatly enhances the value of the data stored.

The method of collecting the data is through the authors. They will be sent, at the same time as the letter of acceptance of their manuscripts, the explanatory booklet and coding forms which give the details and codes of how the data should be submitted to the data bank. Data will be accepted by the editors via disc, tape, cards, or coding forms. The system is simple and is quickly implemented.

The data are likely to be already in tabular form as part of the manuscript, but these data may represent only a part of the total geochemical analytical information gathered by the author and on which the paper is based. The total information is requested for storing in the data bank. The knowledge that complete storage, and therefore subsequent retrievability by interested persons, is available will undoubtedly influence authors in the construction of their manuscript, and should lead to greater economy of use of the printed page. This is not, however, intended to replace completely the printed tabular format of chemical analyses; that will continue.

This new development will permit even wider use of the many good igneous rock analyses becoming available. 


\section{Instructions to authors}

Transactions of the Royal Society of Edinburgh: Earth Sciences appears quarterly, publishing studies on all aspects of the earth sciences and related planetary sciences. Substantial contributions to both information and understanding that emphasise principles and are relevant to a worldwide readership are welcome. Normally there is an upper limit of 25000 words, but most contributions are expected to be shorter. Discussions of papers previously published in the Transactions and reviews of topics of current interest are also invited. There are no page charges but subventions towards cost are welcome. If the use of foldouts or colour illustrations is envisaged, the Editorial Office should be consulted prior to submission.

\section{Submission}

Membership of the Society is not a pre-requisite for submission. Three copies of manuscripts should be sent to the Editorial Office, The Royal Society of Edinburgh, 22 George Street, Edinburgh EH2 2PQ, Scotland. Three copies of illustrations at publication size should also be submitted; for these sets, photocopies of line drawings are adequate, but not of photographs. Illustrations suitable for reproduction (see 3.1) may be requested subsequently. All submissions will be sent to two reviewers. Papers by more than one author must be submitted with a statement signed by each author, to the effect that the paper in its entirety is approved by the joint authors and naming the author who will be responsible for correspondence.

\section{Preparation of papers}

\subsection{Manuscripts}

Manuscripts should be typed on A4 $(295 \times 210 \mathrm{~mm})$ or quarto paper with double spacing throughout and wide margins. A title that is concise and informative, a heading of not more than $\mathbf{5 0}$ typewriter strokes for use at the top of text pages and name(s) of author(s) are to be given on the first page. An abstract of not more than 200 words, intelligible without reference to the text or references, should be given on the second page, with a list of key words not in the title making up no more than 150 typewriter strokes. The text should begin on the third page. Where possible, annotated illustrations and tables should be used in place of text. Give full postal address(es) at the end of the references. Tables and a list of figure captions should be on separate pages.

Editorial details. Words to be printed in italics, e.g. names of taxa, should be underlined. Use capital letters for formal terms only, in both text and headings. The metric system should be used throughout. Abbreviations should omit the full-stop, e.g. $2 \mathrm{~mm}, 3 \mathrm{~km}$ and $6 \mathrm{~kb}$. Compass points are to be abbreviated to N, NW, NW-SE etc. Map references should be in square brackets, e.g. [NM 4437 0293]. Do not use footnotes except in tables. Examples of references in the text are: Jennings and Smith (1967) record .... Bracketed references should be as follows: (James 1931), (Jennings \& Smith 1967, p. 132), (Jenkins 1947, 1950; Brock 1975). Indicate in the margins approximate positions for insertion of illustrations and tables. For particular treatment of palaeontological specialities consult PALAEONTOLOGY 15, 676-81.

\subsection{Headings}

Primary headings, including Acknowledgements and References, are to be numbered 1,2,3 etc. (as in these Instruc- tions) and secondary headings $1.1,1.2,1.3$ etc.; these are to begin at the left-hand margin and should not be underlined. Show tertiary headings by wavy underlining. These should be indented and followed by a full-stop, four spaces and then the text of the sub-section. The introductory section requires no heading. Cross-references in the text should be to a section or sub-section, e.g. (see 2.3), not to a page.

\section{Ilustrations and tables}

\subsection{Illustrations}

Illustrations, labelled figures (Fig. 1,2,3 etc.) are printed within the body of the text at column $(85 \mathrm{~mm})$ or page $(177 \mathrm{~mm})$ width, or page length $(253 \mathrm{~mm})$, but allowance must be made for figure captions. Where appropriate, group material into one figure and label $a, b, c$ etc. In the case of groups of photographs, labels and annotation should be on the appropriate photograph, not in the space between photographs. No lettering should be less than $1 \mathrm{~mm}$ high at reproduction size (the use of capital letters throughout improves clarity after reduction). Transfer lettering is preferred. Large figures can be subdivided for reproduction on facing pages. Photographs should be high quality glossy prints with good contrast at final size and with a scale, or magnification in the caption. In the case of fossil illustrations illumination should be top left. Originals of line drawings are usually required but high quality prints on matt paper at publication size may be acceptable.

\subsection{Tables}

Tables $(1,2,3$ etc.) will generally be set up in type and reproduced at column or page width, although certain tables are better presented using transfer lettering; these should be submitted in the same way as line illustrations. Each table should have a heading and be on a separate sheet. For layout of analytical data see tables published in previous issues. Authors will be asked to send published analyses of igneous rocks to the UK-IGBA file.

\section{References}

Set out as indicated below. Abbreviate journal and series titles according to Part 2 (1975) of BS 4148 (The abbreviation of titles of periodicals. Word-abbreviation list. London: British Standards Institution). This system uses capitals throughout and no full-stops. Authors who are unable to obtain this list should give journal titles in full (in capitals). Indicate volume numbers of journals and series by wavy underlining and book titles by single underlining.

Amstutz, G. C. 1968. Spilites and Spilitic Rocks. In Hess, H. H. \& Poldervaart, A. (eds) Basalts, 737-53. New York: Interscience.

Dick, J. R. F. 1978. On the Carboniferous shark Tristychius arcuatus Agassiz from Scotland. TRANS R SOC EDINBURGH 70, 63-109.

Duff, K. L. 1978. Bivalvia from the English Lower Oxford Clay (Middle Jurassic). PALAEONTOGR SOC MONOGR.

Ferguson, J. \& Currie, K. L. 1971. Evidence of liquid immiscibility in ultrabasic dikes, Ontario. J PETROL 12, 501-85.

Hatch, F. H., Wells, A. K. \& Wells, M. K. 1972. Petrology of the Igneous Rocks, 13th edn. London: George Allen \& Unwin.

\section{Proofs and offprints}

One set of proofs will be sent to the author (or senior author of a joint paper). Fifty free offprints are provided and additional copies can be ordered when proofs are returned. 


\section{TRANSACTIONS OF THE ROYAL SOCIETY OF EDINBURGH: EARTH SCIENCES}

AKPAN, E. B. and FARROW, G. E.

Shell-boring algae on the Scottish continental shelf: identification, distribution, bathymetric zonation

ZHOU, ZHIYI, YIN, GONGZHENG and TRIPP, RONALD P.

Trilobites from the Ordovician Shihtzupu Formation, Zunyi, Guizhou Province, China

JELÍNEK, E., PAČESOVÁ, M., MÍSAŘ, Z., MARTINEC, P. and WEISS, Z.

Geochemistry of a dismembered metaophiolite complex, Letovice, Czechoslovakia 